\title{
Pelayanan Isbat Nikah Wilayah Kerja Kantor Pengadilan Agama Amuntai Kelas 1b Kabupaten Hulu Sungai Utara
}

\author{
Gusti Muhammad Hidayatullah \\ Program Studi Magister Administrasi Publik, Fakultas Ilmu Sosial dan Ilmu Politik, \\ Universitas Lambung Mangkurat \\ Korespondensi : gustimh95@gmail.com
}

\begin{abstract}
Abstrak
Penelitian ini bertujuan untuk mengetahui bagaimana proses pelayanan isbat nikah yang diberikan oleh Kantor Pengadilan Agama Amuntai kepada masyarakat. Penelitian ini menggunakan pendekatan kualitatif dengan teknik pengumpulan data dari hasil observasi, wawancara dan dokumentasi. Hasil penelitian ini menunjukkan bahwa dalam pelayanan isbat nikah pada kantor Pengadilan Agama Amuntai Kelas 1B Kabupaten Hulu Sungai Utara sudah berjalan sesuai harapan hal ini dilihat dari indikator-indikator : Ketepatan Waktu Pelayanan, Akurasi Pelayanan, Kesopanan dan Keramahan dalam Memberikan Pelayanan, Kemudahan Mendapatkan Pelayanan, Kenyamanan dalam Memperoleh Pelayanan, Atribut Pendukung Pelayanan. Sedangkan kendala yang dihadapi yaitu: faktor Data Administrasi Yang Tidak Lengkap, faktor Sarana dan Prasarana Masih Kurang dan faktor Proses yang Cukup Lama.
\end{abstract}

Kata Kunci : Pelayanan, Isbat Nikah, Amuntai

\begin{abstract}
This study aims to determine the service process of accpet of marriage provided by the Religious Court of Amuntai to the community. This study uses a qualitative approach with data collection techniques through observation, interviews, and documentation. This study's results indicate that in the service of marriage service at the Office Religious Court of Amuntai Class 1B, Hulu Sungai Utara Regency has been running as expected, this can be seen from the indicators: Timeliness of Service, Accuracy of Service, Courtesy and Hospitality in Providing Services, Ease of Getting Service Convenience in Obtaining Service, Service Support Attributes. Meanwhile, the constraints faced are: incomplete administrative data factors, insufficient facilities and infrastructure factors, and long process factors.
\end{abstract}

Keywords: Service, Accpet of Marriage, Amuntai

\section{PENDAHULUAN}

Perkawinan adalah hal yang lumrah terjadi pada masyarakat pada umumnya, berlaku untuk semua makhluk-Nya, baik manusia, hewan maupun tumbuhan. Inilah cara yang dipilih Allah SWT sebagai cara makhluk-Nya untuk terus berkembang biak dan melestarikan kehidupan. Manusia sebagai makhluk yang sempurna telah diberi rasa berpikir dan perasaan yang lebih peka dibandingkan makhluk lainnya. Oleh karena itu, perkawinan manusia memiliki tingkat martabat yang lebih tinggi, yaitu kerukunan dan kondisi tertentu yang ditetapkan Allah SWT.

Penelitian ini berangkat dari masalah belum optimalnya pelayanan yang diberikan oleh Kantor Pengadilan Agama Amuntai Kelas 1B Kabupaten Hulu Sungai Utara kepada masyarakat sehingga munculnya keluhan dari masyarakat yang pernah melakukan pelayanan Isbat Nikah tersebut di kantor Pengadilan Agama Amuntai Kelas 1B. Kantor Pengadilan Agama merupakan akses bagi masyarakat guna mendapatkan keabsahan pernikahan di mata hukum dengan cara melakukan isbat nikah yang dulunya dikarenakan masalah belum tercatatnya data pernikahan mereka dan juga permasalahan lainnya. 
Undang-Undang Republik Indonesia Nomor 1 Tahun 1974 tentang Perkawinan Ketentuan pasal 2 klausa 1 dari Kisah Perkawinan menjelaskan bahwa "perkawinan adalah sah jika sesuai dengan hukum setiap agama dan kepercayaan". Ketentuan ini menjelaskan tentang asas perkawinan bangsa Indonesia berdasarkan Pancasila yang bersumber dari penjelasan pasal 2 klausa 1 UU Perkawinan, bahwa perkawinan yang dikontrak sesuai dengan agama masing-masing merupakan asas utama perkawinan yang sah. Pasal 2 (2) Hukum Perkawinan menetapkan: setiap pernikahan didaftarkan sesuai dengan ketentuan perundang-undangan yang berlaku. Keabsahan suatu perkawinan menurut hukum perkawinan didasarkan pada hukum agama dan keyakinannya masing-masing, sehingga sejak berlakunya Undang-undang Perkawinan ini, upacara perkawinan menurut hukum agama sangat menentukan keabsahan suatu perkawinan.Hal ini berakibat banyak orang tidak melakukan pencatatan pada kantor catatan sipil. Sumber: (Undang-Undang Nomor 1 Tahun 1974).

Tata cara perkawinan diatur oleh ketentuan pelaksana hukum perkawinan yaitu Peraturan Pemerintah No. 9 tahun 1975. Dalam Peraturan Pemerintah ini tentang tata cara perkawinan, pasal 10 ayat (2) menyatakan bahwa tata cara perkawinan dilakukan sesuai dengan hukum di setiap agama dan kepercayaan. Dalam ayat (3) dinyatakan bahwa perkawinan diakhiri dengan dihadiri oleh pegawai pencatat, mengikuti tata cara menikah sesuai dengan hukum dan keyakinan agama yang relevan, di hadapan dua orang saksi. Sumber: (Peraturan Pemerintah Republik Indonesia No 9 Tahun 1975 Pelaksana UU No 1 Tahun 1974 tentang Perkawinan).

Tujuan pencatatan perkawinan adalah untuk membentuk tatanan perkawinan dalam masyarakat. Itu adalah upaya hukum untuk melindungi martabat dan kesucian perkawinan dan, lebih khusus lagi, perlindungan perempuan dalam kehidupan rumah tangga dengan pencatatan perkawinan, yang dibuktikan dengan akta nikah, yang setiap suami dan istri menerima salinannya, sehingga jika Sengketa atau Sengketa muncul di antara mereka sebagai akibat dari ketidakkonsistenan. salah satu pihak untuk mencapai cita-cita perkawinan membentuk keluarga sakinah, kemudian pihak lain dapat mengambil langkah hukum untuk mempertahankan atau memperoleh hak-haknya, karena dengan perbuatan tersebut suami istri memiliki bukti yang asli atas perbuatan hukum yang dilakukannya. Sebagaimana tertuang dalam Pasal 7 Inpres no. 1 Tahun 1991 Tentang Distribusi Kumpulan Hukum Islam ("KHI"), yaitu sebagai berikut:

1. Perkawinan hanya dapat dibuktikan dengan Akta Nikah yang dibuat oleh Pegawai Pencatat Nikah.

2. Dalam hal perkawinan tidak dapat dibuktikan dengan Akta Nikah, dapat diajukan isbat nikahnya ke Pengadilan Agama.

3. Pengajuan isbat nikah yang dapat dilakukan pada kantor Pengadilan Agama terbatas mengenai :

a. Adanya perkawinan dalam rangka penyelesaian perceraian;

b. Hilangnya akta nikah;

c. Adanya keraguan tentang sah atau tidaknya salah satu syarat perkawinan;

d. Adanya perkawinan yang terjadi sebelum berlakunya Undang-Undang No. 1 Tahun 1974;

e. Perkawinan yang dilakukan oleh mereka yang tidak mempunyai halangan perkawinan menurut Undang-Undang Nomor 1 Tahun 1974.

4. Yang dapat mengusul permohonan isbat nikah yaitu istrti atau suami, anak kandung mererka, pihak yang berkepentingan dengan perkawinan atau wali nikah.

Undang-Undang Republik Indonesia Nomor 1 Tahun 1974 tentang Perkawinan Ketentuan pasal 2 ayat (1) dari Kisah Perkawinan menjelaskan bahwa "perkawinan adalah sah jika menurut hukum sesuai dengan hukum setiap agama dan kepercayaan". Ketentuan ini menjelaskan tentang asas perkawinan bangsa Indonesia berdasarkan Pancasila yang bersumber dari penjelasan pasal 2 ayat (1) UU Perkawinan, bahwa perkawinan yang dilakukan sesuai dengan agama masing-masing merupakan asas utama perkawinan yang sah. Pasal 2 ayat (2) UU Perkawinan menetapkan: setiap pernikahan didaftarkan sesuai dengan ketentuan perundang-undangan yang berlaku. Keabsahan suatu perkawinan menurut hukum 
perkawinan didasarkan pada hukum agama dan keyakinannya masing-masing, sehingga sejak berlakunya Undang-undang Perkawinan ini, upacara perkawinan menurut hukum agama sangat menentukan keabsahan suatu perkawinan. Akibatnya, banyak orang tidak mendaftar di Kantor Pendaftaran. Sumber: (UU nomor 1 tahun 1974).

Menurut Undang-Undang Nomor 1 Tahun 1974, pengertian perkawinan adalah ikatan jasmani dan rohani antara seorang laki-laki dan seorang perempuan sebagai suami-istri dengan tujuan untuk menciptakan keluarga (rumah tangga) yang bahagia dan kekal berdasarkan Ketuhanan Yang Maha Esa. Di Indonesia, siapa pun yang akan menikah harus mendaftarkan pernikahannya di Kantor Urusan Agama (KUA) untuk Muslim atau Kantor Catatan Sipil (KCS) untuk non-Muslim. Pencatatan ini merupakan bukti otentik sebuah pernikahan, yang juga akan dikonfirmasi dengan akta nikah. Hasil pernikahan yang tidak terdaftar secara hukum tidak sah dan oleh karena itu tidak memiliki kekuatan dan kepastian hukum.Di Indonesia pernikahan yang tidak dicatatkan dikenal dengan pernikahan sirri atau nikah di bawah tangan. Selanjutnya, sebab hal tertentu yang dibenarkan perundang-undangan pernikahan yang tidak dicatatkan, dapat diajukan permohonan penetapan pernikahan di Pengadilan Agama di wilayahnya dengan cara isbat nikah. Isbat nikah adalah penetapan tentang kebenaran (keabsahan) nikah. Pada dasarnya hukum pernikahan adalah mubah (boleh), yaitu pernikahan yang dilakukan tanpa ada faktorfaktor yang mendorong (memaksa) atau yang menghalang-halangi. Dalam Islam batasan usia menikah tidak pasti, bisa disimpulkan menikah pada masa remaja. Bertentangan dengan peraturan perundangundangan, terutama di Indonesia yang telah dikodifikasi sebagai bentuk reformasi hukum keluarga Islam. Di Indonesia, usia minimal untuk menikah sebelumnya telah ditetapkan 19 tahun untuk laki-laki dan 16 tahun untuk perempuan sesuai dengan Undang-undang Nomor 1 Tahun 1974. Pasal. (1), namun pada 2019. Revisi UU No 1 Tahun 1974. Ini menjadi UU No 16 Tahun 2019. Dalam teks UU 16 Tahun 2019. Ketentuan pasal 7 telah diubah sebagai berikut:

1. Perkawinan hanya diizinkan apabila pria dan wanita sudah mencapai umur 19 (sembilan belas) tahun;

2. Dalam hal terjadi penyimpangan terhadap ketentuan umur sebagaimana dimaksud pada ayat (1), orang tua pihak pria dan/atau orang tua pihak wanita dapat meminta dispensasi kepada Pengadilan dengan alasan sangat mendesak disertai bukti-bukti pendukung yang cukup;

3. Pemberian dispensasi oleh Pengadilan sebagaimana dimaksud pada ayat (2) wajib mendengarkan pendapat kedua belah calon mempelai yang akan melangsungkan perkawinan.

Usia minimal menikah bagi perempuan sama dengan usia minimal menikah untuk laki-laki, yaitu 19 (sembilan belas) tahun. Dipercaya bahwa batasan usia adalah pendewasaan mental dan jasmani agar dapat menikah agar dapat mencapai tujuan perkawinan dengan baik tanpa berakhir dengan perceraian dan menerima keturunan yang sehat dan baik.

Sehubungan dengan hal tersebut, terlihat bahwa anak-anak yang berada di bawah usia minimum dapat menikah, dapat mengajukan pencabutan nikah di Pengadilan Agama tempat mereka tinggal untuk mendapatkan surat perintah dari Pengadilan Agama agar dapat menikah dan mendaftarkannya ke Kantor Urusan Agama (KUA). Namun ada yang tidak mengajukan pengabaian karena berbagai alasan, misalnya administrasi yang terlalu ribet, memakan banyak waktu dan biaya. Akibatnya, banyak perkawinan remaja yang tidak terdaftar di Kantor Urusan Agama (KUA). Namun ketika sudah memiliki anak dan anaknya sudah besar nanti akan membutuhkan akta kelahiran, kartu keluarga untuk masuk sekolah, kemudian orang tua menyadari betapa pentingnya mendaftarkan perkawinan untuk mendapatkan akta kelahiran anak demi kekuatan dan kepastian hukum agar ia dan keluarganya memiliki perlindungan. Akhirnya isbat nikah menjadi solusi yang terbaik untuk pasangan tersebut untuk mendapatkan pengakuan di mata hukum.

Masalah sosial selalu ada dan berbeda dari satu daerah ke daerah lain. Tak terkecuali di Amuntai, kota kecil di Provinsi Kalimantan Selatan. Fakta yang terjadi setelah berlakunya Undang-Undang Nomor 1 Tahun 1974 Sebagai dasar perkawinan, masih banyak orang yang tidak mendaftarkan pernikahannya 
secara resmi, sehingga apabila buku nikah merupakan dokumen yang sah perlu dibuatkan akta kelahiran anak, untuk mengetahui ahli waris, TASPEN, pembuatan paspor dan berbagai persyaratan lainnya yang berkaitan dengan buku nikah sebagai syarat administrasi sebagai bukti memiliki buku nikah tidak dapat ditunjukkan. Isbat nikah akhirnya menjadi satu-satunya solusi bagi mereka.

Fenomena di Amuntai adalah banyaknya kasus perkawinan yang disebabkan oleh tidak dibuatnya permohonan pembebasan dari perkawinan bagi pasangan yang menikah di bawah umur yang kemudian melakukan perkawinan siri atau biasa disebut menikah di bawah tangan. Kemudian mereka melamar pernikahan setelah mereka melewati usia pernikahan yang ditentukan dalam undang-undang pernikahan. Hal ini menyebabkan banyaknya perkara perkawinan yang diajukan ke Kantor Pengadilan Agama karena perkawinan tidak masuk ke dalam register Kantor Urusan Agama setempat.

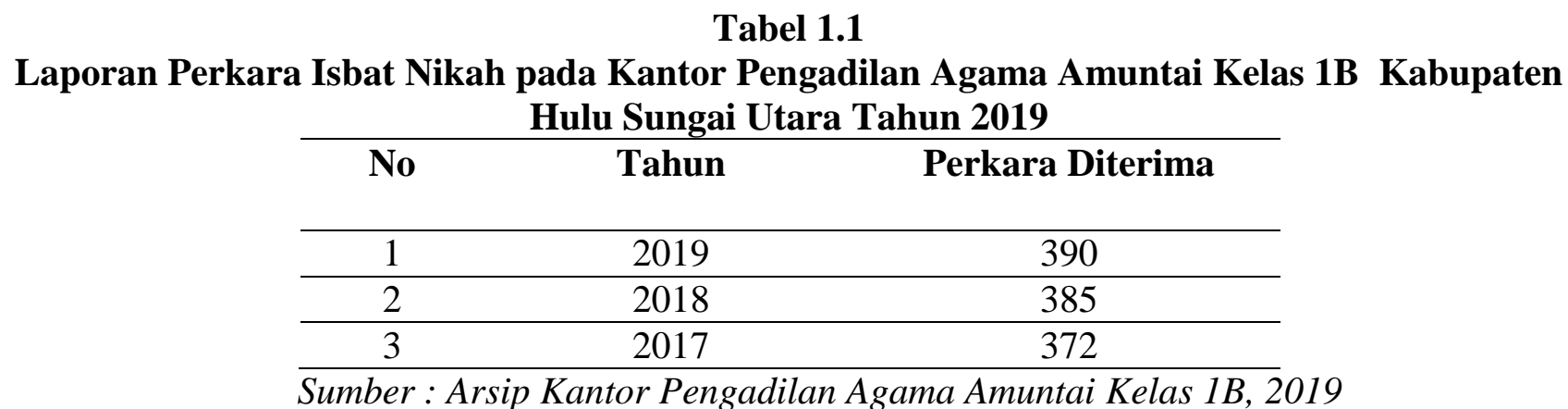

Banyak atau sedikitnya jumlah perkara yang masuk di Kantor Pengadilan Agama Amuntai Kelas 1B Kabupaten Hulu Sungai Utara juga tidak terlepas dari bagaimana pelayanan yang diberikan oleh pihak Pengadilan Agama Amuntai tentang perkara yang ditugaskan untuk melayani masyarakat pencari keadilan. Berdasarkan data diatas tentang perkara isbat nikah yang di Pengadilan Agama Amuntai Kelas 1B Kabupaten Hulu Sungai Utara dari tahun 2017-2019 terjadi peningkatan setiap tahunnya. Sidang isbat yang dilakukan menunjukkan kewajiban pemerintah untuk membantu masyarakat dalam memenuhi haknya untuk memiliki dokumen kependudukan. Dimana, tugas pemerintah adalah mempermudah pelayanan, sehingga hak masyarakat terpenuhi setelah dilaksanakan sidang isbat terhadap pasangan yang telah mendaftarkan tersebut akan mendapatkan buku nikah, sebagai dasar untuk mengurus akta kelahiran anak, kartu identitas anak, dan dokumen kependudukan lainnya.

Oleh karena itu, Pengadilan Agama Amuntai Kelas 1B wajib memberikan pelayanan yang memuaskan kepada masyarakat dalam keberhasilan pelayanan yang diberikan dengan baik. Namun kenyataannya pelayanan yang diberikan masih jauh dari harapan masyarakat. Adanya data administrasi yang tidak lengkap menghambat pelayanan yang diberikan, adanya fasilitas yang masih kurang dan proses yang panjang yang membuat pelayanan menjadi belum maksimal. Berdasarkan penelitian data awal, hal ini membuat pelayanan yang diberikan menajdi kurang prima Hal tersebut diakrnakan adanya komentar dari masyarakat tentang lamanya proses agar bisa mendapatkan buku nikah dari kantor KUA. Sesuai dengan hasil wawancara awal yang dilakukan peneliti pada tanggal 31 Maret 2020 menurut penuturan dari salah satu masyarakat oleh bapak Juraidin dari Kelurahan Sungai Malang yang pernah mengurus prosedur permohonan itsbat nikah di pengadilan agama yaitu:

"Pada prosesnya meurus permohonan isbat nikah agak lambat dan tidak bisa cepat selesainya dan minimal sebulan baru selesai. Persyaratatan yang dipinta kantor Pengadilannya cukup memakan waktu karna harus surat keterangan yang ditandatangani oleh RT." 
Beliau juga menjelaskan mengenai pelayanan yang diberikan oleh pengadilan agama dalam mengurus itsbat nikah yaitu :

"Menurut saya pelayanan yang diberikan oleh Pengadilan Agama Amuntai menurut saya sudah cukup baik, melayani dengan baik dan ramah namun terkadang tidak fokus memberikan pelayanan dari proses yang cukup lama kemudian untuk sarana dan prasarana ada yang masih kurang.".

Berdasarkan hasil wawancara tersebut dapat diketahui prosedur permohonan isbat di pengadilan agama cukup sulit, karena harus melengkapi berkas seperti KTP, kartu keluarga, surat nikah di bawah tangan, dan surat keterangan suami istri. Prosesnya lambat tidak bisa selesai dalam waktu yang cepat. Juga untuk pelayanan bagi masyarakat yang mengurus isbat nikah di Kantor Pengadilan Agama Amuntai Kelas 1B Kabupaten Hulu Sungai Utara juga kurang baik, karena di kantor pengadilan agama tersebut petugas pelayanannya kurang fokus terhadap masyarakat yang melakukan pelayanan dan juga fasilitas yang masih kurang.

Berdasarkan informasi yang didapatkan peneliti dari informasi awal yang didapat oleh peneliti dari warga yang pernah melakukan pelayanan pada kantor Pengadilan Agama perihal isbat nikah ada beberapa faktor yang menjadi masalah dalam pelayanan Isbat Nikah Wilayah Kerja Kantor Pengadilan Agama Amuntai Kelas 1B yaitu :

1. Data administrasi yang tidak lengkap, hal ini menghambat proses pelayanan yang diberikan membuat terhambat karena masyarakat harus melengkapi persyaratan-persyaratan yang diberikan oleh Pengadilan Agama, jika datanya tidak lengkap maka Pengadilan Agama Amuntai tidak dapat melaksanakan persidangan.

2. Masalah sarana dan prasarana. Karena masih ada beberapa fasilitas yang kurang seperti tidak ada fasilitas ruang bermain anak, raungan laktasi dan lain-lain. Hal ini tentunya berdampak besar terhadap pelayanan yang diberikan Kantor Pengadilan Agama Kelas Amuntai Kelas 1B Kabupaten Hulu Sungai Utara kepada mereka yang yang ingin melaksanakan isbat nikah.

3. Proses tunggu panggilan yang lama dan kurangnya kepastian waktu yang diberikan kepada masyarakat yang berperkara isbat nikah dari tahap pendaftaran sampai dengan proses sidang untuk mendapatkan penetapan sah atau tidak sahnya sidang isbat nikah tersebut.

Upaya perbaikan atau penyempurnaan terhadap faktor-faktor layanan akan dapat membantu memberikan nilai tambah serta membawa citra baik. Oleh karena itu aspek persepsi harus dapat ditangkap secara cermat oleh pihak Kantor Pengadilan Agama Amuntai Kelas 1B Kabupaten Hulu Sungai Utara agar dapat menampilkan kinerja sebagai salah satu upaya memberikan pelayanan yang sesuai dengan kebutuhan dan keinginan pengunjung.

Materi tentang pelayanan publik telah memberikan daya tarik tersendiri bagi peneliti untuk dijadikan obyek penelitian. Pelayanan pada saat ini masih belum begitu memuaskan, karena pelayanan yang diharapkan masyarakat atau pengunjung belum begitu sesuai dengan harapan yang diinginkan.

Oleh karena itu peneliti dapat memilih salah satu organisasi pelayanan sebagai subjek penelitian, dan organisasi pelayanan menurut peneliti harus diambil dari unsur pemerintah, karena pemerintah berkewajiban untuk memberikan pelayanan prima kepada rakyatnya. Oleh karena itu, peneliti ingin menarik perhatian pada aspek pelayanan publik dalam kaitannya dengan proses Isbat Nikah yang dilakukan oleh pemberi layanan kepada masyarakat. Maka judul yang diangkat adalah: "Pelayanan Isbat Nikah Wilayah Kerja Kantor Pengadilan Agama Amuntai Kelas 1b Kabupaten Hulu Sungai Utara". 


\section{METODE}

Metode penelitian yang digunakan dalam Penelitian Pelayanan Isbat Nikah Wilayah Kerja Kantor Pengadilan Agama Amuntai Kelas 1B Kabupaten Hulu Sungai Utara adalah metode kualitatif, yaitu untuk mencari dan memperoleh data, informasi dan data terkait dengan melihat langsung objek atau sasaran penelitian. Adapun lokasi penelitian ini adalah Kantor Pengadilan Agama Amuntai Kelas 1B Kabupaten Hulu Sungai Utara. Jalan Empu Mandastana, Kelurahan Sungai Malang, Kecamatan Amuntai Tengah, Kabupaten Hulu Sungai Utara, Provinsi Kalimantan Selatan, Kode Pos: 71471. Teknik Pengumpulan data yang digunakan ialah observasi, wawancara, dan dokumentasi. Analisis data yang digunakan pada penelitian ini menggunakan analisis data yang di kemukan oleh Miles dan Huberman (1984) dengan 4 (empat) tahapan yaitu pengumpulan data, reduksi data, penyajian data, dan verifikasi data.

\section{HASIL DAN PEMBAHASAN}

Peneliti akan membahas mengenai bagaimana proses Pelayanan Isbat Nikah Wilayah Kerja Kantor Pengadilan Agama Amuntai Kelas 1B Kabupaten Hulu Sungai Utara, dan faktor-faktor Yang Mempengaruhi Pelayanan Isbat Nikah Wilayah Kerja Kantor Pengadilan Agama Amuntai Kelas 1B Kabupaten Hulu Sungai Utara.

Berikut ini penjelasan menurut Tjiptono (1997) dalam Hardiyansyah (2018:55) tentang ciri-ciri atau atribut-atribut yang menentukan kualitas pelayanan publik tersebut adalah sebagai berikut :

1. Ketepatan Waktu Pelayanan;

2. Akurasi Pelayanan;

3. Kesopanan dan Keramahan dalam Memberikan Pelayanan;

4. Kemudahan Mendapatkan Pelayanan;

5. Kenyamanan dalam Memperoleh Pelayanan;

6. Atribut Pendukung Pelayanan.

\section{Ketepatan Waktu Pelayanan}

Ketepatan waktu dalam hal memberikan pelayanan kepada masyarakat sangat berpengaruh terhadap suatu pelayanan pada suatu kantor atau instansi terutama pada pemerintahan yang berhubungan langsung kepada masyarakat dalam hal pemberian pelayanan. Waktu yang ditetapkan sejak ditetapkan saat pengajuan permohonan sama dengan waktu penyelesaiaan pelayanan termasuk pengaduan haruslah berkaitan dengan kepastian waktu dalam memberikan playanan yang sesuai dengan lamanya waktu layanan masing-masing hal ini Menurut Keputusan Menteri Pemberdayaan Aparatur Negara No.63 tahun 2003 tentang pedoman umum penyelenggaraan pelayanan publik.

Apabila dalam hal pemberian proses pelayanan tidak ada kepastian waktu maka akan mempengaruhi citra negatif kepada kantor yang memberikan pelayanan tersebut. Seperti yang ada pada proses pelayanan yang diberikan oleh Kantor Pengadilan Agama Amuntai perihal Isbat Nikah.

Hasil dari Penelitian tentang Pelayanan Isbat Nikah Wilayah Kerja Kantor Pengadilan Agama Amuntai Kelas 1B Kabuptaen Hulu Sungai Utara menunjukan bahwa masih belum efektif, karena masyarakat yang melakukan pelayanan harus menunggu lama dalam proses isbat nikah memakan waktu lebih dari satu bulan hal ini dikarenakan dari waktu tunggu pemanggilan sidang yang cukup memakan waktu dan setelah itu harus menunggu lagi untuk mengambil Salinan putusan selama satu minggu apalagi jika persyaratan yang belum lengkap maka proses sidang akan lebih lama lagi. Padahal di zaman modern ini segalanya sudah digitalisasi seharusnya dalam hal memberikan pelayanan tentunya sudah 
dipermudah dan segala proses yang lama bisa dipangkas.

Dari pembahasan tersebut dapat disimpulkan bahwa dalam proses pelayanan isbat nikah msih kurang optimal, karena proses waktu pelayanan yang cukup lama pada saat menunggu panggilan sidang isbat nikah dan tidak ada kepastian waktu dari kantor Pengadilan Agama Amuntai.

\section{Akurasi Pelayanan}

Akurasi pelayanan, yaitu meminimalkan kesalahan dalam hal pelayanan yang diberikan kepada pemakai jasa pada kantor Pengadilan Agama Amuntai Kelas 1B dalam hal memberikan pelayanan kepada masyarakat sudah sesuai dengan SOP di mana pemberian informasi pada saat melakukan pendaftaran sudah berjalan dengan baik, jadi apabila masyarakat yang ingin melakukan pendaftaran harus sudah melengkapi berkas persyaratan yang telah disetujui dari pemberi jasa pelayanan yaitu Kantor Pengadilan Agama Amuntai dan dari penerima jasa pelayanan selaku masyarakat.

Hasil dari Penelitian tentang Pelayanan Isbat Nikah Wilayah Kerja Kantor Pengadilan Agama Amuntai Kelas 1B Kabuptaen Hulu Sungai Utara menunjukan bahwa dalam hal akurasi pelayanan sudah efektif. Setelah proses sidang akan diberikan salinan penetapan, salinan penetapan ini sudah dikerjakan melalui aplikasi khusus sehingga terhindar dari kesalahan dan data yang dikerjakan akan langsung masuk ke kantor pusat sehingga pegawai yang mengerjakan sangat berhati-hati dan minim dalam kesahalan karna akan berpengaruh ke data pusat dan unutk memperbaikinya susah.

Dari pembahasan tersebut dapat disimpulkan bahwa dalam proses pelayanan isbat nikah sudah efektif, karena data yang akan diberikan kepada masyarakat dalam hal ini salinan penetapan sangat minim terjadi kesalahan sehingga membuat masyarakat tidak harus bolak balik ke kantor Pengadilan Agama untuk memperbaiki kesalahan.

\section{Kesopanan dan Keramahan Memberikan Pelayanan}

Kesopanan dan keramahan yang diberikan oleh pada kantor Pengadilan Agama Amuntai Kelas 1B dalam hal ini pegawai yang memberikan pelayanan memberikan pelayan sesuai dengan SOP yang diberikan oleh kantor Pengadilan Agama Amuntai. Dalam hal sikap dan pemberian informasi harus jelas dan pegawai mengerti dan menguasai tentang materi tentang isbat nikah dalam hal syarat dan tat acara prosesnya.

Hasil dari Penelitian tentang Pelayanan Isbat Nikah Wilayah Kerja Kantor Pengadilan Agama Amuntai Kelas 1B Kabuptaen Hulu Sungai Utara menunujukkan bahwa dalam hal kesopanan dan keramahan petugas dalam memberikan pelayanan sudah baik dimana petugas cepat dan sopan dalam memberikan pelayanan sehingga memudahkan dan mempercepat pelayanan yang diberiakn

Dari pembahasan tersebut dapat disimpulkan bahwa dalam proses pelayanan isbat nikah sudah baik karna petugas pelayanannya sopan dalam memberikan pelayanan kepada masyarakat yang melakukan pelayanan pada kantor Pengadilan Agama Amuntai.

\section{Kemudahan Mendapatkan Pelayanan}

Kemudahan dalam mendapatkan pelayanan yang diberikan oleh Kantor Pengadilan Agama Amuntai, dalam hal ini kemudahan pengguna jasa terhadap pelayanan yang diberikan dari petugas yang mudah dicari sehingga mempermudah si penerima jasa dalam melakukan pelayanan dan fasilitas yang mendukung seperti komputer dan jaringan internet.

Hasil dari Penelitian tentang Pelayanan Isbat Nikah Wilayah Kerja Kantor Pengadilan Agama Amuntai Kelas 1B Kabuptaen Hulu Sungai Utara menunujukkan bahwa dalam hal kemudahan pemohon dalam mendapatkan pelayanan Isbat Nikah sudah berjalan cukup baik. Dimana hal ini terlihat dari pegawai yang selalu ada pada bagian pelayanan yang selalu ditempati petugas, juga dalam hal fasilitas 
seperti komputer dan jaringan internet untuk menunjang pekerjaan, akan tetapi masih belum disediakn jaringan internet gratis terhadap masyarakat yang datang ke Kantor Pengadilan Agama Amuntai.

Dari pembahasan tersebut dapat disimpulkan bahwa dalam proses pelayanan isbat nikah sudah cukup baik dari segi petugas dan fasilitasnya, akan tetapi pemberian layanan dalam hal ini jaringan internet gratis kepada masyarakat yang ingin melakukan pelayanan pada kantor Pengadilan Agama Amuntai masih belum mendapatkan layanan jaringan internet gratis.

\section{Kenyamanan dalam Memperoleh Pelayanan}

Kenyamanan dalam memperolah pelayanan yang diberikan kantor Pengadilan Agama Amuntai kepada si penerima layanan dalam hal ini yaitu masyarakat yang mana pihak Pengadilan Agama sudah memberikan sarana berupa tempat parkir yang luas, ruang tunggu yang nyaman dan layanan khusus pemberian informasi dan penanganan yang disediakan di bagian frontliner juga aksesnya yang mudah dijangkau karena berada di wilayah khusus perkantoran Pemerintah Kabupaten Hulu Sungai Utara.

Hasil dari Penelitian tentang Pelayanan Isbat Nikah Wilayah Kerja Kantor Pengadilan Agama Amuntai Kelas 1B Kabuptaen Hulu Sungai Utara menunujukkan bahwa dalam hal kenyamanan dalam memperolah pelayanan masih kurang, dimana masyarakat masih mengeluhkan tidak adanya tempat khusus atau ruangan khusus untuk bermain anak-anak dan juga tidak adanya ruangan laktasi sehinga masyarakat agak kesulitan jika membawa anak kecil ataupun bayi. Akan tetapi kantor Pengadilan Agama sudah menyiapkan dalam hal ini tempat mushola, parkir yang luas dan juga tempat khusus merokok.

Dari pembahasan tersebut dapat disimpulkan bahwa dalam proses pelayanan isbat nikah dalam hal ini kenyamanan dalam memperoleh pelayanan masih belum optimal dikarenakan masih adanya keluhan dari masyarakat yaitu tidak disediakannya tempat khusus ibu menyusui/laktasi dan tempat bermain anak-anak sehingga masyarakat yang melakukan pelayanan terutama dalam hal proses sidang isbat nikah kesusahan jika membawa anak kecil.

\section{Atribut Pendukung Pelayanan}

Atribut pendukung pelayanan yang diberikan oleh kantor Pengadilan Agama Amuntai kepada masyarakat yang ingin melakukan pelayanan isbat nikah telah disediakan untuk memberikan rasa nyaman kepada masyarakat yang datang ke kantor Pengadilan Agama.

Hasil dari Penelitian tentang Pelayanan Isbat Nikah Wilayah Kerja Kantor Pengadilan Agama Amuntai Kelas 1B Kabuptaen Hulu Sungai Utara menunujukkan bahwa dalam hal atribut pendukung pelayanan sudah berjalan dengan baik yang mana dari kantor Pengadilan memberikan ruang tunggu yang nyaman dengan memberikan $\mathrm{AC}$ dan tempat ruang pelayanan yang luas, juga dalam hal kebersihan kantor baik di dalam dan luar kantor selalu diperhatikan dan juga diberikan papan informasi dan banner sehingga masyarakat yang datang bisa mendapatkan informasi dini sebelum ke petugas pelayanannya dalam hal berkisar pada Pengadilan Agama.

Dari pembahasan tersebut dapat disimpulkan bahwa dalam proses pelayanan isbat nikah dalam hal ini atribut pendukung pelayanan sudah berjalan optimal dimana dapat dilihat dari segi ruang tunggu yang nyaman dan dari segi kebersihan kantor yang selalu dipantau juga tersedianya papan-papan informasi sehingga mempermudah masyarakat mendapatkan informasi dini. 


\section{KESIMPULAN}

Berdasarkan hasil penelitian pembahasan di atas bahwa proses pelayanan isbat nikah wilayah kerja Kantor Pengadilan Agama Amuntai Kelas 1B Kabupaten Hulu Sungai Utara sudah berjalan secara optimal walaupun masih ada kekurangan yang masih harus diperbaiki dalam hal pelayanan yang diberikan kepada masyarakat oleh kantor Pengadilan Agama Amuntai Kelas 1B Kabupaten Hulu Sungai Utara. Hal ini berdasarkan indikator-indikator pelayanan publik yang dikemukakan oleh Tjiptono (1997) dalam Hardiyansyah (2018:55) yaitu variabel yang pertama tentang ketepatan waktu pelayanan, dalam proses waktu pelayanan yang masih cukup lama pada saat mendapatkan jadwal surat panggilan pelaksanaan sidang dan tidak diberikan kepastian waktu kepada masyarakat. Variabel yang kedua yaitu akurasi pelayanan, dalam hal ini sudah berjalan optimal dimana tidak ditemukannnya keluhan dari masyarakat karna saat proses pelaksanaannya tidak mengalami kesalahan baik saat sidang dan pemberian salinan putusan kepada masyarakat. Variabel yang ketiga yaitu kesopanan dan keramahan dalam memberikan pelayanan, sudah berjalan baik dimana petugas sopan dan responsif saat memberikan pelayanan kepada masyarakat. Variabel yang keempat yaitu kemudahan mendapatkan pelayanan, sudah berjalan cukup baik akan tetapi dalam hal ini masih adanya keluhan dari masyarakat dalam hal prasarana yang masih kurang. Variabel yang kelima yaitu kenyamanan dalam memperoleh pelayanan juga masih kurang optimal dikarenakan adanya keluhan dari masyarakat dalam hal fasilitas yang masih kurang seperti tidak adanya tempat bermain anak kecil dan ruang laktasi. Variabel yang keenam yaitu atribut pendukung pelayanan sudah berjalan dengan baik dari segi pemberian informasi, ruang tunggu yang nyaman, dan kebersihan kantor yang selalu dijaga.

Adapun faktor-faktor yang menghambat pelayanan isbat nikah wilayah kerja kantor Pengadilan Agama Amuntai Kelas 1B Kabupaten Hulu Sungai Utara ada empat faktor yaitu yang pertama data administrasi yang tidak lengkap akan membuat proses sidang menjadi lebih lama. Kedua Sarana dan prasarana masih kurang seperti tidak adanya ruang bermain anak, ruang laktasi dan jaringan internet gratis kepada pengunjung. Ketiga proses cukup lama, perlu memakan waktu sebulan lebih untuk bisa mendapatkan buku nikah dari KUA.

\section{SARAN}

Berdasarkan hasil penelitian dan kesimpulan diatas maka peneliti mencoba merekomendasikan beberapa hal dalam rangka meningkatkan proses pelayanan pada Kantor Pengadilan Agama Amunta Kelas 1B Kabupaten Hulu Sungai Utara sebagai berikut :

1. Sebaiknya selalu berbenah dalam memberikan pelayanan yang terbaik bagi masyarakat dengan memperbaiki segala aspek yang dianggap masih kurang dan melakukan perencanaan yang lebih baik. Seperti melakukan evaluasi sebulan sekali terhadap kinerja setiap pegawai terutama kepada petugas yang memberikan pelayanan.

2. Mempersingkat proses waktu tunggu panggilan sidang yang memakan waktu kurang lebih satu bulan, di zaman era 4.0 ini segalanya sudah digitalisasi dan segala informasi bisa diberikan melalui media online sehingga segala akses yang seharusnya memakan waktu lama bisa cepat diproses.

3. Melengkapi fasilitas sarana dan prasarana yang kurang dengan bekoordinasi dengan pihak terkait. 


\section{DAFTAR PUSTAKA}

[1] Agus Dwiyanto, 2005, Mewujudkan Good Governance melalui Pelayanan Publik. Yogyakarta : UGM Press.

[2] Asasriwarni, "Kepastian Hukum "Itsbat Nikah" Terhadap Status Perkawinan, Anak dan Harta Perkawinan” dari http://www.nu.or.id, diunduh pada 5 Mei 2015

[3] Hardiyansyah. (2018). Kualitas Pelayanan Publik, (Edisi Revisi). Yogyakarta: Gava Media.

[4] Hayat. (2017). Manajemen Pelayanan Publik. Jakarta: PT.Raja Grafindo Persada.

[5] Hasan, Damsyi, "Permasalah Isbat Nikah (Kajian terhadap Pasal 2 UU. No. 1 Tahun 1974 dan pasal 7 KHI)” Artikel dalam Mimbar Hukum, No. 31, Jakarta: Al-Hikmah dan Ditbinbapera Islam, 1997.

[6] Gunawan, Imam. (2015).Metode Penelitian Kualitatif Teori \& Praktik. Jakarta: PT. Bumi Aksara.

[7] Ibrahim, Amin. 2008. Teori dan konsep pelayanan publik serta implementasinya. Bandung: Mandar Maju

[8] Idrus, Muhammad. (2009). Metode Penelitian Sosial: pendekatan kualitatif dan Kuantitatif edisi kedua. Yogyakarta : PT Glora Aksara Pratama. Jakarta : PT.Raja Grafindo Persada.

[9] Kumorotomo, Wahyudi. 2018. Etika Administrasi Negara. Jakarta : PT.Raja Grafindo Persada.

[10] Maksudi, Beddy Iriawan. 2017. Dasar-Dasar Administrasi Publik. Jakarta : PT.Raja Grafindo Persada.

[11] Manan, Abdul. Penerapan Hukum Acara Perdata Di Lingkungan Peradilan Agama. Jakarta :Kencana. 2008.

[12] Moenir. (2008). Manajemen pelayanan umum di Indonesia. Jakarta : PT Bumi Aksara.

[13] Moleong. 2011. Metodologi Penelitian Kualitatif. Bandung: PT. Remaja RosdakaryaPemberdayaan Perempuan Kepala Keluarga (PEKKA). "Panduan Pengajuan Itsbat Nikah". Laporan Penelitian-JAustralia Indonesia Partnership, Jakarta, 2012.

[14] Salim, Nasruddin. "Isbat Nikah Dalam Kompilasi Hukum Islam (Tinjauan Yuridis, Filosofis Dan Sosiologis), Dalam Mimbar Hukum Aktualisasi Hukum Islam, No. 62 Th. XIV Jakarta: Yayasan Al hikmah.

[15] Sidik, Mu'min Maulana, "Istbat Nikah bagi Pelaku Nikah Sirih (Perkawinan di Bawah Tangan) Studi Kasus di Pengadilan Agama Karawang Jawa Barat”, Skripsi, UIN Syarif Hidayatullah, 2010.

[16]Soemiyati. 2004. Hukum Perkawinan Islam Dan Undang-Undang Perkawinan. Liberty : Yogyakarta 
[17] Sugiono. (2009). Metode Penelitian Kuantitif \& $R \& D$. Bandung: Alfabeta

[18] Tim Penyusun (2013). Pedoman Penulisan Tesis. Banjarmasin. Pustaka Banua Banjarmasin. 